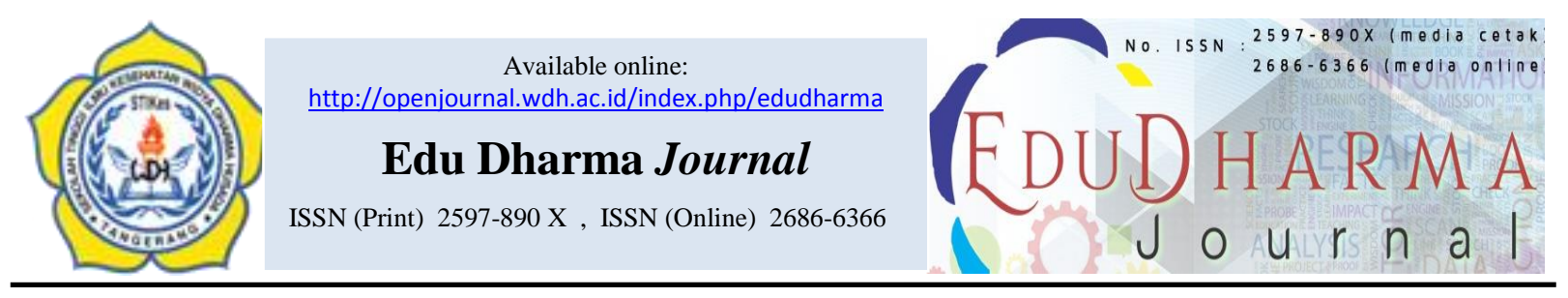

\title{
GAMBARAN SISTEM PENDISTRIBUSIAN OBAT DI APOTEK KAWIJAYA TAHUN 2018
}

Nurwulan Adi Ismaya ${ }^{1 *}$, Christina Apnirosi Sitorus ${ }^{2}$, Lela Kania Rahsa Puji ${ }^{3}$, Tri Okta Ratnaningtyas ${ }^{4}$, Nur Hasanah ${ }^{5}$, Fenita Purnamasari Indah ${ }^{6}$

${ }_{1,2,3,4,5,6}$ STIKes Kharisma Persada, Jalan Pajajaran No.1, Pamulang, Tangerang Selatan 15417, Indonesia

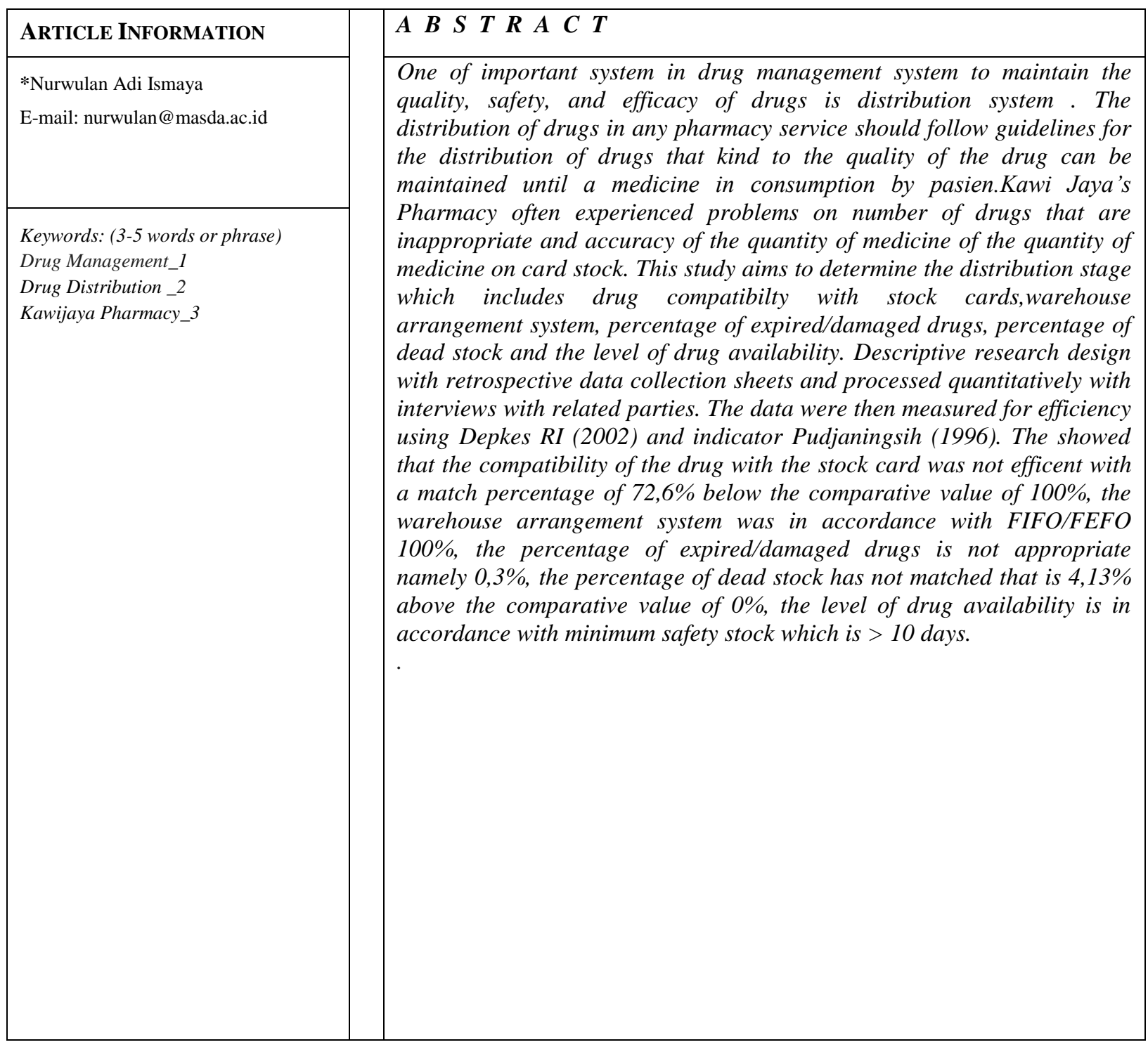




\begin{tabular}{|c|c|}
\hline $\begin{array}{c}\text { Kata Kunci: (3-5 kata atau frase) } \\
\text { Pengelolaan Obat_1 } \\
\text { Distribusi Obat_2 } \\
\text { Apotek Kawijaya_3 }\end{array}$ & $\begin{array}{l}\text { A B S T R A K } \\
\text { Salah satu sistem pengelolaan obat yang penting untuk menjaga kualitas, } \\
\text { keamanan, dan efikasi obat adalah sistem pendistribusian obat. Sistem ini } \\
\text { hendaknya mengikuti pedoman Cara Distribusi Obat yang Baik untuk } \\
\text { menjaga mutu obat.Apotek Kawijaya Pamulang sering mengalami } \\
\text { permasalahan atas jumlah obat yang tidak sesuai dan ketepatan jumlah } \\
\text { obat ketepatan jumlah obat pada kartu stok. Tujuan penelitian ini adalah } \\
\text { melihat kerasionalan sistem distribusi obat yang meliputi kecocokan obat } \\
\text { dengan kartu stok, sistem penataan gudang, persentase obat } \\
\text { kadaluarsa/rusak, persentase stok mati dan tingkat ketersediaan obat. } \\
\text { Penelitian ini termasuk dalam penelitian deskripti dengan data retrospektif. } \\
\text { Data dikumpulkan menggunakan lembar pengumpul data dan diolah } \\
\text { secara kuantitatif disertai wawancara pada pihak terkait. Data tersebut } \\
\text { kemudian diukur efisiensinya menggunakan indikator Depkes RI (2002) } \\
\text { dan Pudjaningsih (1996). Hasil penelitian menunjukkan bahwa kecocokan } \\
\text { obat dengan kartu stok belum efisien dengan persentase kecocokan } 72,6 \% \\
\text { dibawah nilai pembandingnya yaitu } 100 \% \text {, sistem penataan gudang sudah } \\
\text { sesuai FIFO/FEFO } 100 \% \text {, persentase obat kadaluarsa/rusak tidak sesuai } \\
\text { yaitu 0,3\%, persentase stok mati belum sesuai yaitu } 4,1 \% \text { diatas nilai } \\
\text { pembandingnya yaitu 0\%, tingkat ketersediaan obat sudah sesuai minimal } \\
\text { safety stok yaitu >10 hari. Sebaiknya dilakukan penelitian lebih lanjut } \\
\text { untuk mencari penyebab ketidaksesuaian sistem distribusi obat. }\end{array}$ \\
\hline & $\begin{array}{l}\text { This is an open access article under the CC-BY-NC-SA license. } \\
\text { (C) } 2020 \text { Some rights reserved }\end{array}$ \\
\hline
\end{tabular}




\section{PENDAHULUAN}

Salah satu sistem pengelolaan obat yang berperan dalam menjaga kualitas, keamanan, dan efikasi obat adalah sistem pendistribusian obat. Distribusi obat pada setiap pelayanan kefarmasian hendaknya mengikuti pedoman Cara Distribusi Obat yang Baik untuk menjaga mutu obat(Amelia, Albarda, \& Trinovani, 2015; Hartini \& Marchaban, 2017; Sinen, Astuty, \& Sri, 2017).

Di Indonesia masih banyak terdapat masalah dalam sistem pendistribusian, diantaranya adalah penjualan obat di tempat yang tidak ada ijin dari dinas kesehatan atau bukan di tempat pelayanan kefarmasian, pembelian obat keras tanpa resep dokter, pembelian obat tidak sesuai indikasi dan atau diagnosis. Hal ini akan membahayakan masyarakat. (Amelia et al., 2015; Hartini \& Marchaban, 2017; Iqbal, Geer, \& Dar, 2016).

Apotek merupakan salah satu pelayanan kefarmasian yang langsung berhubungan dengan pasien, oleh karena itu perlu dilakukan evaluasi terhadap sistem distribusi obat di apotek. Hasil penelitian terhadap apotek-apotek di Sleman-Yogyakarta menunjukkan bahawa sistem pendistribusian obat belum $100 \%$ sesuai dengan CDOB. Sekitar $88 \%$ apotek harus diberikan peringatan keras, dan $11,11 \%$ apotek harus non aktif waktu(Hartini \& Marchaban, 2017; Iqbal et al., 2016).
Apotek Kawijaya merupakan apotek dengan harga yang relatif murah yang terletak di Pamulang. Masalah yang terdapat pada apotek Kawijaya adalah masih terdapat jumlah obat tidak sesuai dan ketepatan jumlah obat dengan kartu stok.

Masih tingginya masalah dalam sistem distribusi di Indonesia khususnya di Apotek, membuat penulis tertarik untuk meneliti tentang Gambaran Sistem Pendistribusian Obat di Apotek Kawijaya Pamulang. Agar terlaksananya pendistribusian obat secara merata dan teratur sehingga dapat diperoleh pada saat dibutuhkan.

\section{METODE PENELITIAN}

Penelitian deskriptif dengan data retrospektif yaitu pengambilan data yang sudah ada pada tahun sebelumnya. Bahan penelitian menggunakan lembar observasi data terkait berupa lembar stok, laporan obat kadaluarsa / rusak, laporan obat tidak bergerak Penelitian ini berlokasi di Apotek Kawijaya Pamulang, selama 2 minggu dari tanggal 20 April-11 Mei 2019. Populasi dari penelitian ini adalah seluruh jenis obat yang ada di Apotek Kawijaya Pamulang tahun 2018 yang berjumlah 1500 obat sebagai objek penelitian dan juga seluruh 
pihak Apotek Kawijaya Pamulang yang terdiri dari Apoteker Penanggung jawab Apotek sebagai subjek penelitian.

Metode sampling yang digunakan untuk menentukan sampel pada objek penelitian yaitu menggunakan non probability sampling dengan metode total sampling.
Dalam penelitian ini penulis juga melakukan proses wawancara dengan apoteker penanggungjawab apotek.

\section{HASIL PENELITIAN}

\section{Kesesuaian jumlah obat dengan kartu stok}

Tabel 1. Hasil Pengambilan Data Tahap Distribution (Ketepatan Data Jumlah Obat Pada Kartu Stok) Tahun 2018

\begin{tabular}{lcc}
\hline Indikator & Nilai Pembanding & Hasil \\
\hline $\begin{array}{l}\text { Kesesuaian jumlah obat dengan kartu } \\
\text { stok }\end{array}$ & $100 \%$ (Pudjaningsih,1996) & $72,6 \%$ \\
\hline
\end{tabular}

Berdasarkan tabel 1 diketahui ketepatan data jumlah obat pada kartu stok yaitu 72,6\%, maka pengelolaan obat pada indikator tersebut tidak sesuai.

\section{Sistem Penataan Gudang}

Tabel 2. Hasil Pengambilan Data Tahap Distribution (Sistem Penataan Gudang) Tahun 2018.

\begin{tabular}{llll}
\hline \multicolumn{1}{c}{ Indikator } & \multicolumn{2}{c}{ Nilai Pembanding } & Hasil \\
\hline $\begin{array}{l}\text { Sistem penataan } \\
\text { (Pudjaningsih,1996) }\end{array}$ & gudang & $\begin{array}{l}100 \% \\
\text { (Pudjaningsih, 1996) }\end{array}$ & $\begin{array}{c}\text { FIFO/FEFO } \\
100 \%\end{array}$ \\
\hline
\end{tabular}

Berdasarkan tabel 2 diketahui sistem penataan gudang yaitu 100\% maka, pengelolaan obat pada indikator tersebut sesuai.

\section{Persentase dan Nilai Obat yang Kadaluarsa dan atau Rusak}

Tabel 3. Hasil Pengambilan Data Tahap Distribution (Persentase dan Nilai Obat yang Kadaluarsa dan atau Rusak) Tahun 2018.

\begin{tabular}{|c|c|c|c|}
\hline Indikator & & Nilai Pembanding & Hasil \\
\hline $\begin{array}{l}\text { Persentase dan nilai obat } \\
\text { kadaluarsa dan atau } \\
\text { (Pudjaningsih,1996) }\end{array}$ & $\begin{array}{l}\text { yang } \\
\text { rusak }\end{array}$ & $\leq 0,2 \% \quad$ (Pudjaningsih, 1996) & $0,3 \%$ \\
\hline
\end{tabular}


Berdasarkan tabel 3 diketahui persentase dan nilai obat yang kadaluarsa dan atau rusak yaitu $0,3 \%$, maka pengelolaan obat pada indikator tersebut tidak sesuai.

\section{Persentase Stok Mati}

Tabel 4. Hasil Pengambilan Data Tahap Distribution (PersentaseStok Mati) Tahun 2018.

\begin{tabular}{ccc}
\hline Indikator & Nilai pembanding & Hasil \\
\hline Persentase stok mati (Pudjaningsih, 1996) & $0 \%$ (Pudjaningsih, 1996) & $4,1 \%$ \\
\hline
\end{tabular}

Berdasarkan tabel 4 diketahui persentase stok mati yaitu 4,1\% maka, pengelolaan obat pada indikator tersebut tidak sesuai.

\section{Tingkat Ketersediaan obat}

Tabel 5. Hasil Pengambilan Data Tahap Distribution (Tingkat Obat) Tahun 2018.

\begin{tabular}{cl|ll|}
\hline Indikator & \multicolumn{1}{|c|}{ Nilai Pembanding } & \multicolumn{2}{|c|}{ Hasil } \\
\hline $\begin{array}{c}\text { Tingkat ketersediaan obat } \\
\text { (Pudjaningsih, 1996) }\end{array}$ & $\begin{array}{l}\text { Minimal safety stok } \\
\text { (Pudjaningsih, 1996) }\end{array}$ & $\begin{array}{l}\text { Safety }>\text { 10 hari } \\
\text { stok }\end{array}$ \\
\hline
\end{tabular}

Berdasarkan tabel 5 diketahui tingkat ketersediaan obat yaitu minimal safety stok maka, pengelolaan obat pada indikator tersebut menunjukkan sesuai minimal safety stok.

\section{PEMBAHASAN}

1. Kesesuaian jumlah obat dengan kartu Stok

Tujuan dari parameter ini adalah untuk melihat ketelitian petugas gudang. Hasil persentase tersebut didapatkan dengan cara mengambil 10\% kartu stok dan dilakukan pencocokan dengan jumlah obat. Dari hasil ini diperoleh persentase nilai untuk indikator ini sebesar 72,6\%. Hal ini dikarenakan petugas bagian gudang kurang teliti dalam mengisi kartu stok sehingga terjadi ketidaksesuaian antara jumlah obat dengan kartu stok. Hasil ini tidak sesuai dengan penelitian Pudjaningsih (1996) yang mendapatkan persentase $100 \%$.

Penelitian yang sama terkait kesesuaian jumlah obat dengan kartu stok di RSUD Tarakan Jakarta Pusat sebanyak 93,27\% (Purwidyaningrum, 2011) dan Rumah Sakit PKU Muhammadiyah Temanggung memberikan hasil 55,92\% (Fakhriadi dkk, 2011). 
2. Sistem Penataan Gudang

Tujuan dari parameter ini adalah melihat sistem penataan gudang. Hasil persentase tersebutkan didapatkan dari hasil wawancara kepada petugas gudang. Dari hasil persentase sistem penataan gudang menunjukkan persentase nilai untuk indikator ini sebesar $100 \%$. Karena seluruh obat di Apotek Kawijaya Pamulang telah menggunakan sistem yang pertama yaitu FEFO (First Expired First Out) yaitu penyimpanan obat sesuai tanggal kadaluarsa terdekat, sistem yang kedua adalah FIFO (First In First Out) yang penyimpanan obat sesuai dengan tanggal kedatangan tercepat. Hasil penelitian ini sudah sesuai dengan penelitian Pudjaningsih yaitu $100 \%$.

Penelitian serupa terkait sistem penataan gudang di Instalasi Farmasi RSUD dr. R. Soedjono Selong Lombok Timur memberikan hasil 100\% (Nurul Qiyaam, 2016).

3. Persentase dan Nilai Obat Yang Kadaluarsa dan Atau Rusak

Tujuan dari parameter ini adalah untuk melihat persentase obat kadaluarsa dan atau rusak. Persentase obat yang kadaluarsa dan atau rusak di Apotek
Kawijaya Pamulang menunjukkan persentase nilai untuk indikator ini sebesar $0.3 \%$. Hasil ini tidak sesuai dengan penelitian Pudjaningsih dengan nilai $\leq 0,2 \%$.

4. Persentase Stok Mati

Parameter ini bertujuan untuk melihat obat yang tidak mengalami pergerakan selama 3 bulan. Hasil persentase didapatkan dari laporan daftar item tidak bergerak selama tiga bulan. Hasil persentase menunjukkan persentase nilai untuk indikator ini sebesar $4,1 \%$. Hal ini disebabkan obat yang bergerak lambat (slow moving). Hasil persentase tersebut jika dibandingkan dengan penelitian Depkes RI (2002) yang mendapatkan $0 \%$ maka, penilaian persentase stok mati tidak sesuai.

Penelitian serupa terkait persentase stok mati yang dilakukan adalah di Instalasi Farmasi Rumah Sakit Ortopedi Prof. DR. R. Soeharso Surakarta memberikan hasil 3,33\% (Heru Sasongko, 2014) dan di Instalasi Farmasi RSUD Karel Sadsuitubun Kabupaten Maluku Tenggara memberikan hasil 5\% (Wirdah Wati, 2012). 
5. Tingkat Ketersediaan Obat

Tujuan dari parameter ini adalah untuk mengetahui ketersediaan obat. Hasil yang diperoleh dari kartu stok obat menunjukkan hasil yaitu tingkat ketersediaan obat di Apotek Kawijaya rata-rata > 10 hari. Hal ini disebabkan terbatasnya persediaan untuk obatobat tertentu. Hasil tersebut jika dibandingkan dengan penelitian Depkes RI (2002) dengan minimal safety stok maka, hasil tingkat ketersediaan obat sudah safety stok.

6. Penelitian serupa terkait tingkat ketersediaan obat yang dilakukan di Instalasi Farmasi Rumah Sakit Universitas Gadjah Mada memberikan hasil 18,4 bulan (Farina Dwipa Assanti, 2014) dan di Instalasi Farmasi RSUD Dr. M.M Dunda Limboto Tahun 2015 memberikan hasil 163 hari (Siska Saskia Talani, 2016).

\section{KESIMPULAN}

1. Diketahui ketepatan data jumlah pada kartu stok yaitu $72,6 \%$.

2. Diketahui sistem penataan gudang yaitu FIFO/FEFO 100\%.

3. Diketahui persentase nilai obat yang kadaluarsa dan atau rusak yaitu $0,3 \%$.
4. Persentase stok mati yaitu $4,1 \%$.

5. Diketahui hasil tingkat ketersediaan obat minimal safety stok yaitu $>10$ hari.

\section{DAFTAR PUSTAKA}

Amelia, Y., Albarda, A., \& Trinovani, E. (2015). Sistem Informasi untuk Monitoring Distribusi Obat di Indonesia. Jurnal Edukasi Dan Penelitian Informatika (JEPIN), 1(1), 45-52. https://doi.org/10.26418/jp.v1i1.10 14

Hartini, I. S., \& Marchaban, M. (2017). Evaluasi Pelaksanaan Cara Distribusi Obat Yang Baik (Cdob) Pada Apotek Di Kecamatan Mlati Kabupaten Sleman Yogyakarta. Majalah Farmaseutik, 12(1), 394398. Retrieved from https://journal.ugm.ac.id/majalahfar maseutik/article/view/24133

Iqbal, M. J., Geer, M. I., \& Dar, P. A. (2016). Medicines management in hospitals: A supply chain perspective. Systematic Reviews in Pharmacy, 8(1), 80-85. https://doi.org/10.5530/srp.2017.1.1 4

Sinen, Y., Astuty, W., \& Sri, H. (2017). Evaluasi Penyimpanan Dan Pendistribusian Obat Di Pt. Unggul Jaya Cipta Usaha Manado. Jurnal Ilmiah Farmasi UNSRAT, 6(4), 19.

Departemen Kesehatan RI. (2014). Keputusan Menteri Kesehatan Republik Indonesia Nomor 1197/Menkes/SK/X/2004. Tentang 
Standar Pelayanan Minimal Rumah Sakit. Jakarta.

Departemen Kesehatan RI. (2006). kebijakan Obat Nasional, 8, Departemen Kesehatan RI. Jakarta.

Heru Sasongko dkk. (2014). Evaluasi Distribusi dan Penggunaan Obat Paien Rawat Jalan Di Rumah Sakit Ortopedi. Universitas Gadjah Mada. Yogyakarta.

Mahmud Badaruddin. (2016). Gambaran Pengelolaan Persediaan Obat di Gudang Farmasi RSUD Kota Sekayu. Jurnal.

Nurul Qiyaam. (2016). Evaluasi Manajemen Penyimpanan Obat Di Gudang Obat Instalasi Farmasi RSUD $d r$. R. Soedjono Lombok Timur. Jurnal.

Pudjaningsih,D. (1996). Pengembangan Indikator Efisiensi Pengelolaan Obat di Farmasi RS. Program Pasca Sarjana. Fakultas Kedokteran. Universitas Gadjah Mada. Yogyakarta.

Peraturan Pemerintah RI. (2009). Peraturan Pemerintah Republik Indonesia Nomor 51 Tahun 2009 Tentang Pekerjaan Kefarmasian. Jakarta: Menteri Hukum dan HAM RI. Jakarta.

Peraturan Menteri Kesehatan RI Nomor 35 tahun 2014 Tentang Standar Pelayanan kefarmasian Di Apotek. Jakarta.

Peraturan Menteri Kesehatan RI Nomor 73 tahun 2016 Tentang Standar
Pelayanan Kefarmasian Di Apotek. Jakarta.

Quick.J.D. Rankin.J.R. Laing. R.O. O'Cornor.R.W. (2012). Hogerzeil. H.V. Dukes. M.N.G. Garnett. A.1997. Managing Drug Supply. Second edition. revised and expanded. 4.14.33. Kumarin Press. West Harford.

Soemantri, Anggiani, P. (2013). Evaluasi Pengelolaan Obat Di Instalasi Farmasi Rumah Sakit Umum Daerah Dr. Moewardi. Skripsi, Universitas Muhammadiyah Surakarta. 